\title{
Analysis of Deformation Data of a Deep Foundation Pit in Karst Poor Geological Conditions Wei-yu Wang ${ }^{1}$, Xing-Gao ${ }^{2}$, Qi-Zhao ${ }^{3}$
}

\author{
${ }^{1,2}$ Hebei Jian Ke Tang Qin Building Science and Technology Co. Ltd. \\ ${ }^{3}$ College of Civil Engineering Hebei University, Baoding, Hebei, China
}

\begin{abstract}
This paper is based on a deep foundation pit project under the geological conditions of karst. The monitoring data is analyzed, and the deformation rule of the foundation pit is obtained. At the same time, the influence factors of foundation pit deformation are studied, and the relationship between the displacement of slope of foundation pit at different stages is studied. Get conclusions as following, in the excavation of the foundation pit, the different supporting forms of foundation pit have great influence on the horizontal displacement of foundation pit. The horizontal displacement deformation of slope at the excavation stage is larger, accounting for 68\% 78\% of total deformation. The horizontal displacement deformation of slope at the backfill stage is significantly smaller, accounting for $22 \%$ 32\% of the total deformation.
\end{abstract}

Keywords - Foundation pit; deformation analysis, The foundation pit monitoring, Horizontal deformation of slope top, The vertical displacement of the slope.

\section{INTRODUCTION}

The deformation analysis of foundation pit is based on the phenomenon of deformation. The causes and factors of deformation are analyzed. Thorough study of deep foundation pit deformation mechanism, the foundation pit deformation is effectively controlled, and the stability of foundation pit is maintained. At present, at home and abroad, many scholars have studied the deformation of deep foundation pit. $\mathrm{Woo}^{[1]}, \mathrm{Ou}^{[2]}, \mathrm{Wong}^{[3]}$ studied the relationship between the maximum lateral

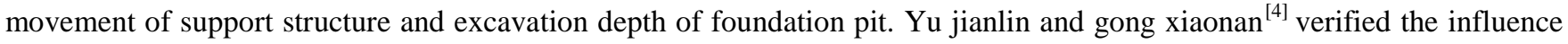
of space effect on deep foundation pit. Sun jianping and wei huanwei ${ }^{[5]}$ showed that the horizontal displacement and subsidence ratio of slope top of foundation pit gradually tended to value over time. This paper mainly studies the effect of different supporting forms on the deformation of deep foundation pit. Meanwhile, the relationship between the displacement of slope of foundation pit at different stages is studied.

\section{GENERAL SITUATION OF ENGINEERING}

The length of foundation pit is $198.3 \mathrm{~m}$ and width $87.5 \mathrm{~m}$. The grade of foundation pit safety is grade one. The bottom elevation of the foundation is $-10 \mathrm{~m}$, and the excavation depth is about $11 \mathrm{~m}$. The east of $20 \mathrm{~m}$ is Xueyuan Road, the south side of $5 \mathrm{~m}$ is the hospital road, and the west side of $10 \mathrm{~m}$ is the hospital hardening road. The south side of the foundation pit adopts the pile bolt support, and the other parts are supported by bolts. The number of monitoring points for foundation pit is 18, the horizontal displacement monitoring points and settlement monitoring points are shared. s1, s2, s3, s4, s5, s6, s7, s8, s9, s10 are bolt support, s11, s12, s13, s14, s15, s16, s17 are pile anchor support. The layout of the measuring points is shown in Figure 1.

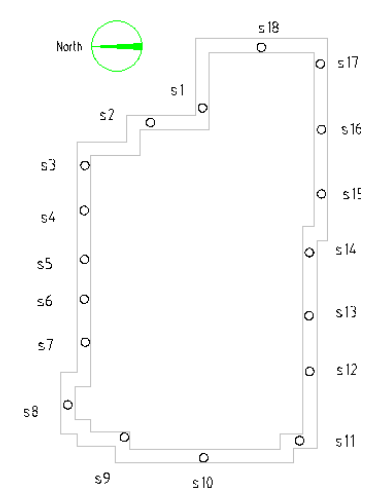

FIGURE 1. LAYOUT OF MONITORING POINTS

The lithology of the engineering field is divided into 14 layers from top to bottom, as shown in Table 1. 
TABLE 1

SOIL PARAMETERS

\begin{tabular}{|c|c|c|c|c|c|}
\hline Layer & Thickness/m & $\begin{array}{c}\text { Modulus of } \\
\text { compressibility (MPa) }\end{array}$ & $\begin{array}{c}\text { Gravity } \\
\text { density }\left(\mathbf{k N} / \mathbf{m}^{3}\right)\end{array}$ & $\begin{array}{c}\text { Cohesion } \\
c_{k}(\mathbf{k P a})\end{array}$ & $\begin{array}{c}\text { Internal friction } \\
\text { angle }\left(^{\circ}\right)\end{array}$ \\
\hline Miscellaneous fill & $0.30 \mathrm{~m} \sim 1.40 \mathrm{~m}$ & & & & \\
\hline Silty soil & $0.40 \sim 2.40 \mathrm{~m}$ & 5.18 & 19.3 & 26.4 & 22.8 \\
\hline Fine sand & $0.80 \mathrm{~m} \sim 2.70 \mathrm{~m}$ & $12^{*}$ & $20.3^{*}$ & $3.0^{*}$ & $23.0^{*}$ \\
\hline Fine sand & $6.70 \mathrm{~m} \sim 9.10$ & $14^{*}$ & $20.6^{*}$ & $3.0^{*}$ & $26.0^{*}$ \\
\hline Clay & $1.30 \mathrm{~m} \sim 4.50 \mathrm{~m}$ & 6.86 & 17.8 & 38.2 & 17.5 \\
\hline Fine sand & $0.50 \mathrm{~m} \sim 3.40 \mathrm{~m}$ & $22^{*}$ & $20.0^{*}$ & $2.0^{*}$ & $28.0^{*}$ \\
\hline Clay & $0.80 \mathrm{~m} \sim 5.20$ & 7.18 & 17.9 & 35.4 & 19.8 \\
\hline Fine sand & $0.40 \mathrm{~m} \sim 3.60 \mathrm{~m}$ & $25^{*}$ & $20.3^{*}$ & $0^{*}$ & $31.0^{*}$ \\
\hline Silty clay & $2.40 \mathrm{~m} \sim 6.10$ & 7.89 & 19.0 & 36.1 & 22.0 \\
\hline Fine sand & $5.80 \mathrm{~m} \sim 8.10$ & $26^{*}$ & $20.4^{*}$ & $2.0^{*}$ & $30.0^{*}$ \\
\hline Clay & $0.40 \mathrm{~m} \sim 6.60 \mathrm{~m}$ & 7.40 & 18.8 & 62.2 & 23.2 \\
\hline Fine sand & $0.40 \mathrm{~m} \sim 5.40 \mathrm{~m}$ & $28^{*}$ & $20.4^{*}$ & $0^{*}$ & $30.0^{*}$ \\
\hline Pebble & $1.20 \mathrm{~m} \sim 4.70 \mathrm{~m}$ & $42^{*}$ & $20.2^{*}$ & $0^{*}$ & $36.0^{*}$ \\
\hline
\end{tabular}

Note: take * as empirical value

The main unfavorable geological action of the site is karst collapse. There are carbonate rocks in the lower strata of downtown Tangshan. Carbonate is eroded by ground water to form karst caves. After the development of the karst cavity, the permeability is good, and the pipeline has a flow pattern. It has enough storage and diversion space, and can guide a large number of fine materials. An energy release zone is formed along the structural fracture zone under the action of crustal stress and earthquake dynamics. The red clay impermeable layer between the soil and the rock mass is affected. The endless supply of karstic water causes erosion of the soil on the upper part of it. Over time, "soil caves" are formed, leading to land subsidence.

\section{DEFORMATION ANALYSIS}

Two support methods are adopted in the supporting process of the foundation pit. The south side adopts pile bolt support mode. The other sections are supported by bolts. In the analysis of deformation data, in order to analyze the deformation of the foundation pit conveniently, two kinds of support methods are explored respectively.

\subsection{Deformation Analysis of Pile Anchor Support Form}

The foundation pit project is divided into two stages: foundation pit excavation and backfill stage. The excavation is a process of stress unloading, and the backfill stage is at the bottom of the loading process of stress. The stress mechanism of foundation pit in two stages is different, so two stages are considered separately

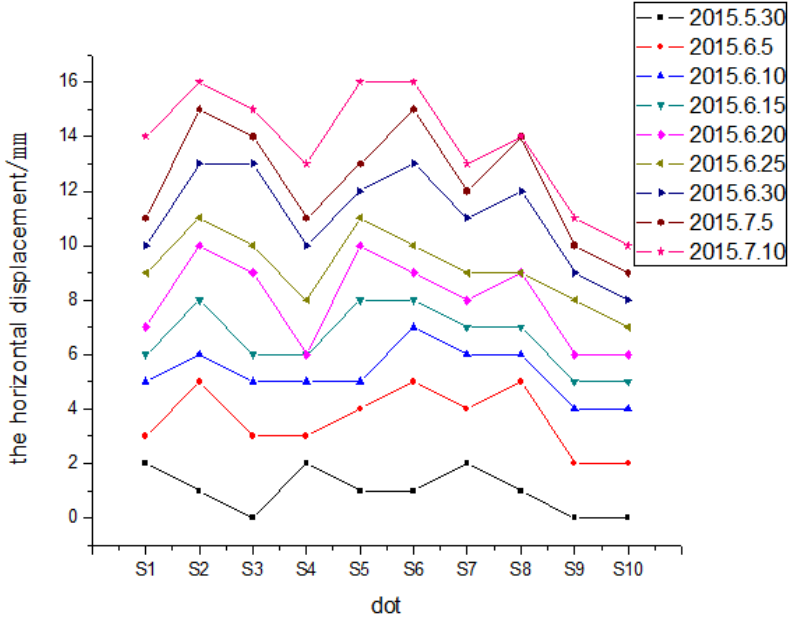

FigURE 2. THE HORIZONTAL DISPLACEMENT OF DIFFERENT TIME S1 S10

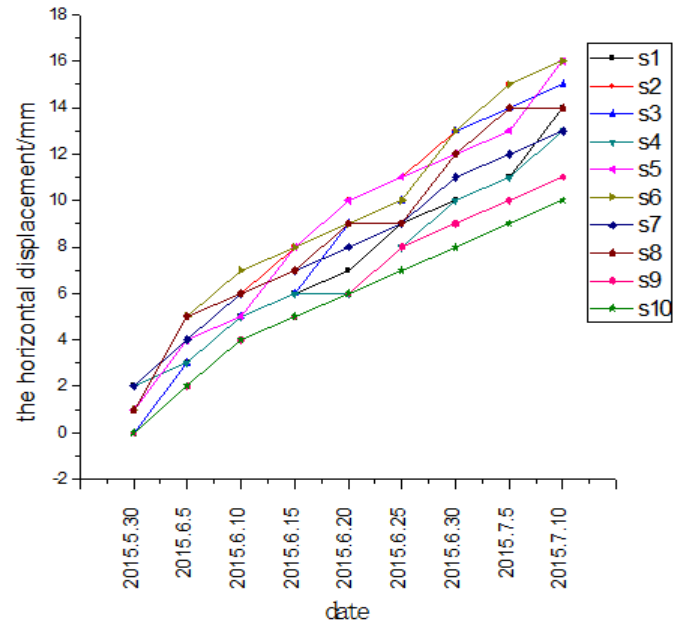

FIGURE 3. THE HORIZONTAL DISPLACEMENT CURVE OF S1 S10 CHANGES WITH TIME 
Figure 2 shows that in the stage of excavation, bolt supporting monitoring points of s1 s10 under different time the amount of the horizontal displacement. Figure 3 shows that in the stage of excavation, curve of horizontal displacement of bolt supporting monitoring points of s1 s10 with time change. According to Figure 2 and Figure 3, the horizontal direction of the foundation pit excavation stage of inward migration trend is very obvious. With the increase of excavation depth, the horizontal displacement is increasing. The maximum horizontal displacement during the excavation slope is located in the middle part of the rectangular pit on the north side of S5 point and S6 point. They reach $16 \mathrm{~mm}$. The analysis finds that the effects caused by space, the horizontal displacement of the slope top increases and reaches the maximum. The minimum displacement point is located in the west of the pit near the southwest corner of the S10.The displacement is only $11 \mathrm{~mm}$.Through analysis, it is found that the monitoring point S10 is closer to the side of the pile anchor support structure, and is affected by the two supporting forms in the excavation process. The constraint of S10 point is the superposition of two supporting forms on the soil mass.

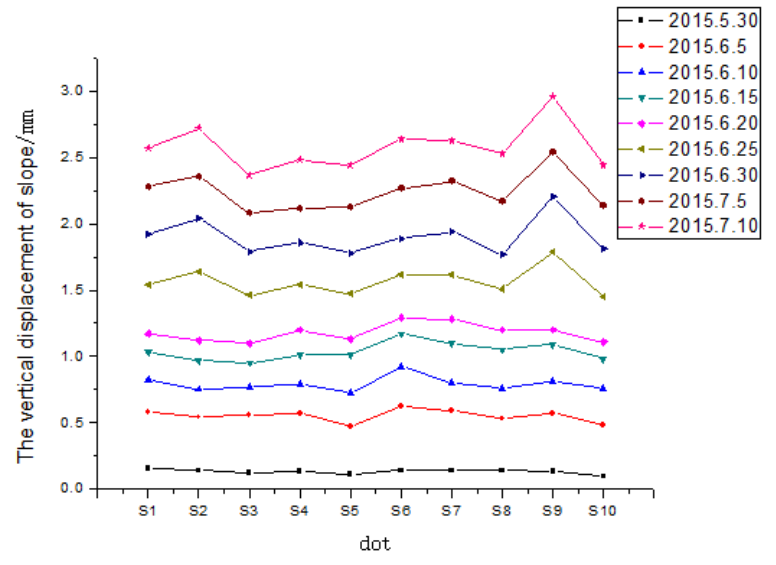

FIGURE 4. THE VERTICAL DISPLACEMENT AT DIFFERENT TIME S1 S10

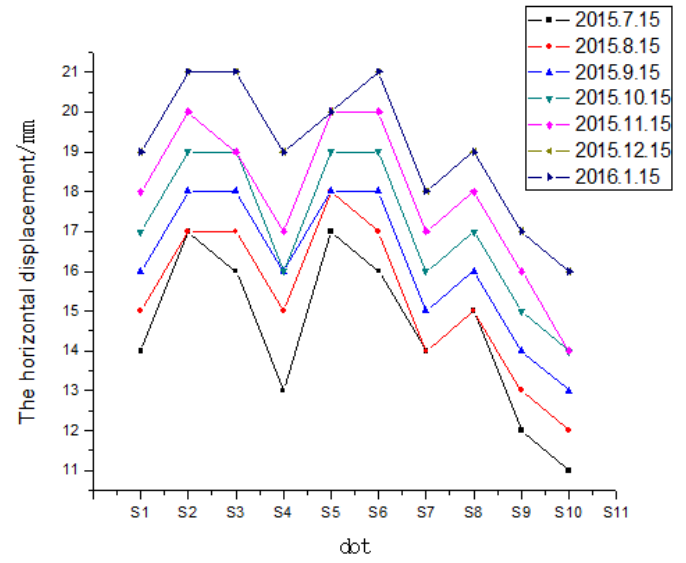

FIGURE 5. THE HORIZONTAL DISPLACEMENT OF DIFFERENT TIME S1 S10

Figure 4 shows that in the stage of excavation, bolt supporting monitoring points of s1 s10 under different time the amount of the vertical displacement. As can be seen from figure 4 the vertical displacement of foundation pit slope is increasing, the growth rate is relatively stable. The overall settlement of the enclosure structure is even. In the bolting period, the maximum vertical displacement of slope displacement is in the northwest corner location S9 and reach 3.10 mm. After analysis, the S9 point is the positive angle. In addition, in the vicinity of the S9 point, there is a 6 story building. Due to the dual role of temporary load and space function, the point of foundation pit is easy to be damaged; the vertical displacement is relatively large.

Figure 5 shows that in the stage of backfill, bolt supporting monitoring points of s1 s10 under different time the amount of the horizontal displacement. It can be seen from Figure 5 that the deformation of the retaining structure is restrained and the deformation rate is slowed down. The analysis shows that the deformation of the retaining structure is restrained after the base cushion and the floor are poured and rammed. The horizontal displacement of s1 s10 monitoring points with time the growth rate is more uniform.

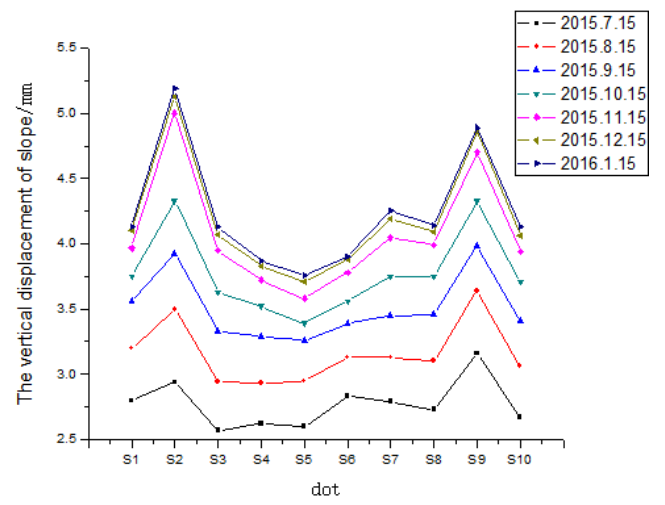

\section{FIGURE 6. THE VERTICAL DISPLACEMENT AT DIFFERENT TIME S1 S10}

Figure 6 shows that in the stage of backfill, bolt supporting monitoring points of s1 s10 under different time the amount of the vertical displacement. .As can see from figure 6, during the construction of underground and main structure, vertical 
displacement of foundation pit slope is increasing. The settlement rate decreases with time, and finally tends to 0 . The maximum vertical displacement of the foundation pit supported by the bolt is located at the S2 point near the northeast corner, reaching $5.19 \mathrm{~mm}$. There is a lot of open space near the S2 site for accumulating building material. Large displacement of vertical displacement of S2 point is caused by surcharge loading.

\subsection{Deformation Analysis of pile Anchor Support Form}

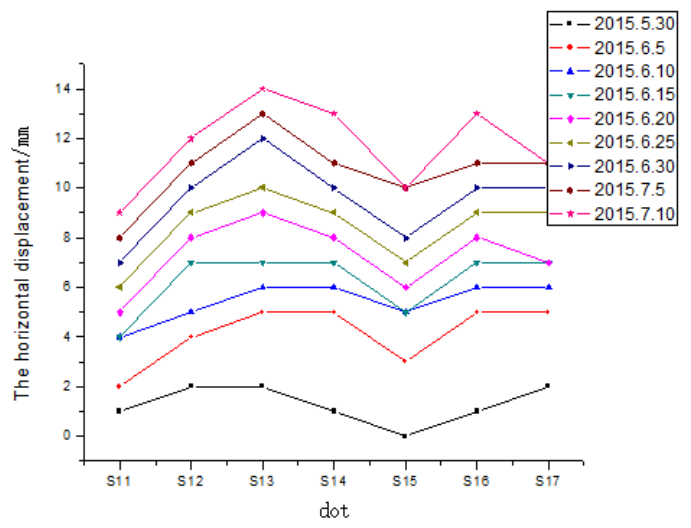

FIGURE 7. THE HORIZONTAL DISPLACEMENT OF DIFFERENT TIME S11 S17

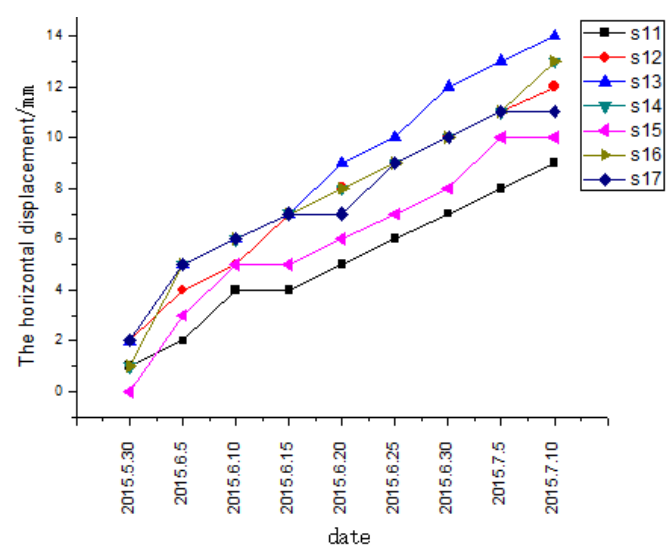

FigURE 8. THE HORIZONTAL DISPLACEMENT CURVE OF S11 S17CHANGES WITH TIME

Figure 7 shows that in the stage of excavation, pile bolt supporting monitoring points of s11 s17 under different time the amount of the horizontal displacement. Figure 8 shows that in the stage of excavation, curve of horizontal displacement of pile bolt supporting monitoring points of s11 s17 with time change. See from figure 7 and figure 8 , the horizontal displacement increases steadily with time. The maximum horizontal displacement of the foundation pit under this type of support is S13 point, reaching $14 \mathrm{~mm}$. The monitoring point is located at the middle side of the south side of the foundation pit. The analysis is caused by the space action of the foundation pit. In the southwest corner, the displacement of the monitoring point S11 at the junction of the two supporting forms is the minimum, reaching $9 \mathrm{~mm}$. S11 point is bound by two kinds of support forms. It can inhibit the deformation of S11 point.

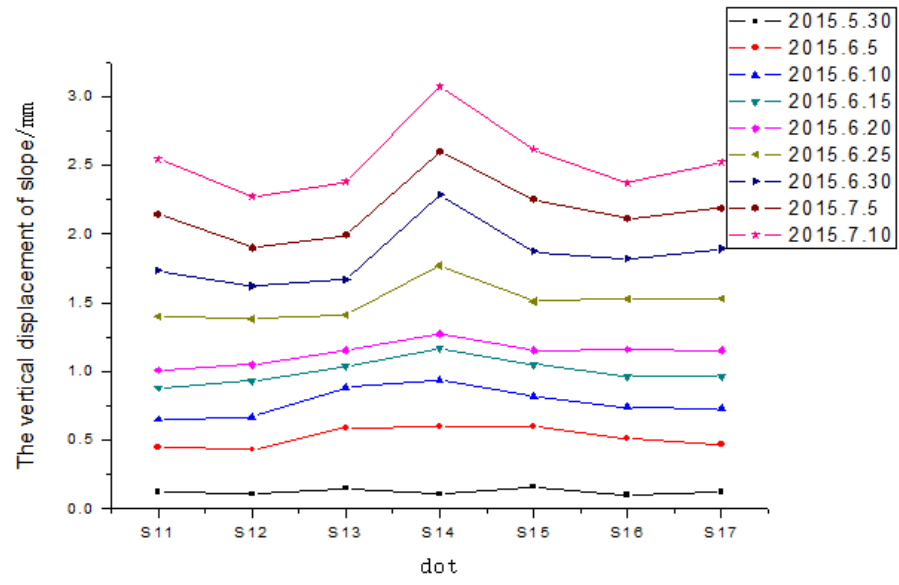

FIGURE 9. THE VERTICAL DISPLACEMENT AT DIFFERENT TIME S11 S17

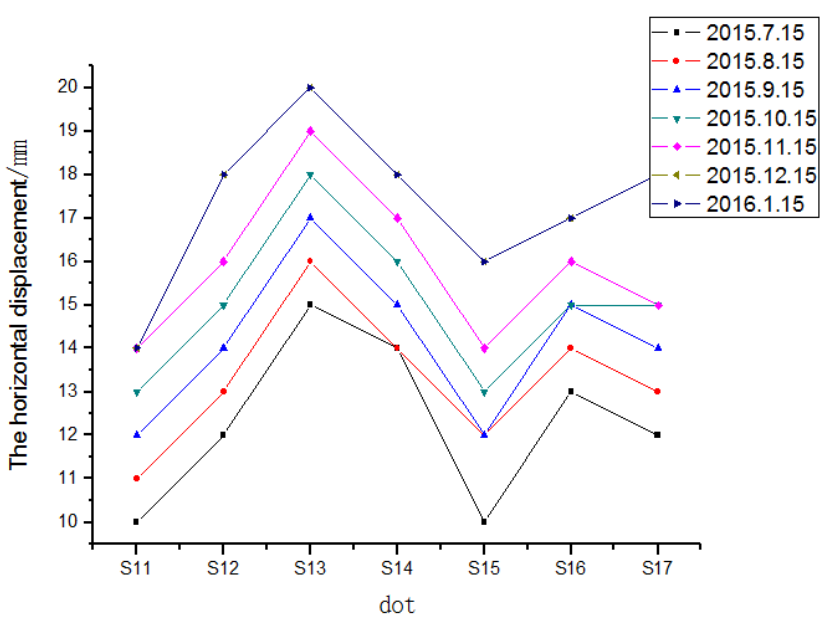

FIGURE 10. THE HORIZONTAL DISPLACEMENT OF DIFFERENT TIME S11 S17

Figure 9 shows that in the stage of excavation, pile bolt supporting monitoring points of s11 s17 under different time the amount of the vertical displacement. As can be seen from the figure 9, the accumulated value of the overall settlement is increasing. The settlement of the retaining structure is more uniform as a whole. In the stage of excavation, the maximum vertical displacement of foundation pit slope is $\mathrm{S} 14$, reaching $3.07 \mathrm{~mm}$. The $\mathrm{S} 14$ point is located at the middle of the long side of the south side of the foundation pit and is close to the positive angle. The S14 point is located on the south side of the foundation pit, near the street. At the same time, the S14 point is not only the middle point of the south side of the foundation pit, but also the positive angle. Because of the space effect and the force relation, this is the weakest place of the whole foundation pit. 
Figure 10 shows that in the stage of backfill, pile bolt supporting monitoring points of s11 s17 under different time the amount of the horizontal displacement. As can be seen from the figure 10, the main body structure construction stage, the horizontal displacement of all monitoring points evenly along increases with the time. The horizontal deformation rate increases steadily.

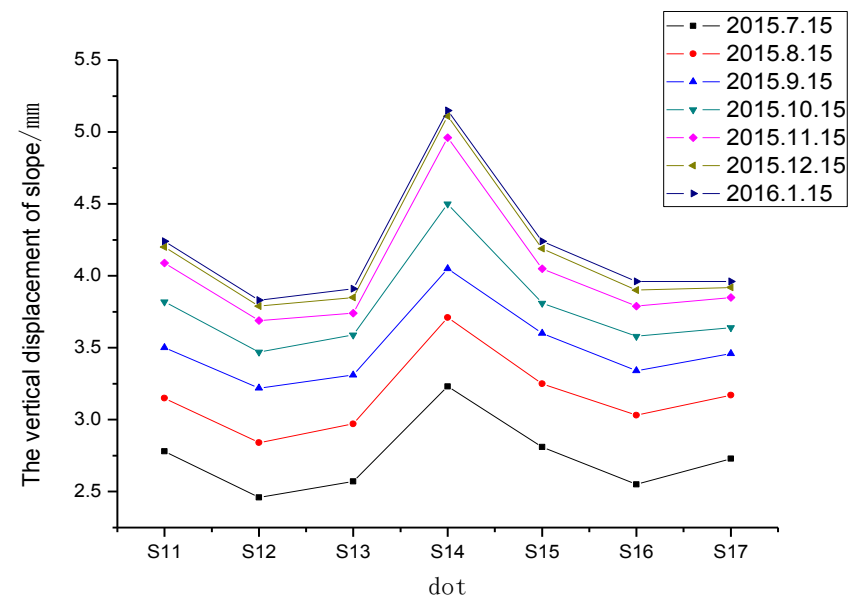

FIGURE 11. THE VERTICAL DISPLACEMENT AT DIFFERENT TIME S1 S10

Figure 11 shows that in the stage of backfill, pile bolt supporting monitoring points of s11 s17 under different time the amount of the vertical displacement. Figure 11 can be seen from the main structure of the construction stage, foundation pit deformation tends to be smooth. Monitoring points does not occur mutation. The vertical displacement of all monitoring points the growth rate gradually decreases. Deformation gradually convergences.

\subsection{Comparative Analysis of Deformation between Bolt and Pile Anchor Support}

\section{TABLE 2}

ANCHOR AND ANCHOR PILE SUPPORT FORM SLOPE DISPLACEMENT IN EXCAVATION STAGE

\begin{tabular}{|c|c|c|c|c|c|c|}
\hline \multirow[b]{2}{*}{ Support form } & \multicolumn{3}{|c|}{ The horizontal displacement } & \multicolumn{3}{|c|}{ The vertical displacement } \\
\hline & $\begin{array}{c}\text { Maximum } \\
\text { displacement/ } \\
\text { mm }\end{array}$ & $\begin{array}{c}\text { Average } \\
\text { displacement/ } \\
\text { mm }\end{array}$ & $\begin{array}{c}\text { Minimum } \\
\text { displacement/ } \\
\text { mm }\end{array}$ & $\begin{array}{c}\text { Maximum } \\
\text { displacement/ } \\
\text { mm }\end{array}$ & $\begin{array}{c}\text { Average } \\
\text { displacement/ } \\
\text { mm }\end{array}$ & $\begin{array}{l}\text { Minimum } \\
\text { displacement } \\
/ \mathrm{mm}\end{array}$ \\
\hline Bolt support & 17 & 14.3 & 11 & 3.10 & 2.702 & 2.49 \\
\hline $\begin{array}{l}\text { Pile anchor } \\
\text { Support }\end{array}$ & 14 & 12.14 & 10 & 3.19 & 2.673 & 2.40 \\
\hline
\end{tabular}

Table 2 shows the anchor and pile anchor supporting slope top displacement at excavation stage. Can be seen from table 2 , bolting slope maximum horizontal displacement at the excavation stage is s2 point. It is located near the northeast corner of the foundation. The horizontal deformation amount is $17 \mathrm{~mm}$. The average horizontal displacement is $14.3 \mathrm{~mm}$. Pile bolting slope maximum horizontal displacement at the excavation stage is s13 point, which is located near south side long edge midpoint displacement of the pit. The maximum horizontal deformation is only $14 \mathrm{~mm}$, and the average horizontal displacement is $12.14 \mathrm{~mm}$. Due to pile force control on slope deformation, resulting in the horizontal deformation of pile anchor is less than the horizontal deformation of bolt. Under the pile anchor support mode, the horizontal displacement change rate is smaller, and the change is more uniform. In the analysis of the maximum horizontal displacement of slope, the bolt support form is $3 \mathrm{~mm}$ larger than the pile anchor support form. In the analysis of the average horizontal displacement of slope, the bolt support form is $2.16 \mathrm{~mm}$ larger than the pile anchor support form. The effect of different supporting forms on the horizontal displacement of the excavation stage is large.

It can be seen from table 2, bolting slope maximum vertical displacement at the excavation stage is s9 point. It s located in the northwest corner. The maximum vertical deformation amount is $3.10 \mathrm{~mm}$. The average displacement is $2.702 \mathrm{~mm}$. Pile bolting slope maximum vertical displacement at the excavation stage is s14 point, which is located the south side of the foundation pit. The deformation is only $3.19 \mathrm{~mm}$, and the average displacement is $2.673 \mathrm{~mm}$. In the analysis of the maximum vertical displacement of slope, the bolt support form is $0.09 \mathrm{~mm}$ larger than the pile anchor support form. In the analysis of the average vertical displacement of slope, the bolt support form is $0.029 \mathrm{~mm}$ larger than the pile anchor support form. The effect of different supporting forms on the vertical displacement of the excavation stage is small. 
TABLE 3

ANCHOR AND ANCHOR PILE SUPPORT FORM SLOPE DISPLACEMENT IN BACKFILL STAGE

\begin{tabular}{|c|c|c|c|c|c|c|}
\hline \multirow{2}{*}{ Support form } & \multicolumn{3}{|c|}{ The horizontal displacement } & \multicolumn{3}{c|}{ The vertical displacement } \\
\cline { 2 - 7 } & $\begin{array}{c}\text { Maximum } \\
\text { displacement/ } \\
\text { mm }\end{array}$ & $\begin{array}{c}\text { Average } \\
\text { displacement/ } \\
\text { mm }\end{array}$ & $\begin{array}{c}\text { Minimum } \\
\text { displacement// } \\
\text { mm }\end{array}$ & $\begin{array}{c}\text { Maximum } \\
\text { displacement// } \\
\text { mm }\end{array}$ & $\begin{array}{c}\text { Average } \\
\text { displacement/ } \\
\text { mm }\end{array}$ & $\begin{array}{c}\text { Minimum } \\
\text { displacement/ } \\
\text { mm }\end{array}$ \\
\hline Bolt support & 17 & 14.3 & 11 & 3.10 & 2.702 & 2.49 \\
\hline $\begin{array}{c}\text { Pile anchor } \\
\text { support }\end{array}$ & 14 & 12.14 & 10 & 3.19 & 2.673 & 2.40 \\
\hline
\end{tabular}

Table 3 shows the anchor and pile anchor pile supporting form slope displacement in backfill stage. Can be seen from table 3 , bolting slope maximum horizontal displacement at the backfill stage is s9 point. It s located in the northwest corner. The horizontal deformation amount is $6 \mathrm{~mm}$. The average horizontal displacement is $4.8 \mathrm{~mm}$. The maximum horizontal displacement of pile anchor supporting the top level is $6 \mathrm{~mm}$, and the average horizontal displacement is $5.18 \mathrm{~mm}$. In the analysis of the maximum horizontal displacement of slope, two kinds of supporting forms are the same. In the analysis of the average horizontal displacement of slope, the bolt support form is $0.34 \mathrm{~mm}$ smaller than the pile anchor support form. The effect of different supporting forms on the horizontal displacement of the backfill stage is small.

Can be seen from table 2, the maximum vertical displacement of pile anchor supporting is S2, which is located near the northeast corner of the foundation pit. The maximum vertical deformation amount is $2.34 \mathrm{~mm}$. The average displacement is $1.537 \mathrm{~mm}$. The maximum vertical displacement of pile anchor supporting is $\mathrm{S} 14$, which is located the south side of the foundation pit. The deformation is only $1.96 \mathrm{~mm}$, and the average displacement is $1.51 \mathrm{~mm}$. In the analysis of the maximum vertical displacement of slope, the bolt support form is $0.803 \mathrm{~mm}$ larger than the pile anchor support form. In the analysis of the average vertical displacement of slope, the bolt support form is $0.027 \mathrm{~mm}$ larger than the pile anchor support form. The monitoring points of bolting slope of the maximum vertical displacement are S2 point. S2 point settlement is caused by the piling up of building materials, and the support structure has nothing to do with it. The effect of different supporting forms on the horizontal displacement of the backfill stage is small.

\section{RELATIONSHIP BETWEEN FOUNDATION PIT DEFORMATION AT EXCAVATION STAGE AND BACKFILL STAGE}

TABLE 4

THE HORIZONTAL DISPLACEMENT OF THE EXCAVATION STAGE AND FILLING STAGE OF PROPORTION

\begin{tabular}{|c|c|c|c|c|c|c|c|c|c|}
\hline dot & $\mathbf{s 1}$ & $\mathbf{s 2}$ & $\mathbf{s 3}$ & $\mathbf{s 4}$ & $\mathbf{s 5}$ & $\mathbf{s 6}$ & $\mathbf{s 7}$ & $\mathbf{s 8}$ & $\mathbf{s 9}$ \\
\hline $\begin{array}{c}\text { Accumulative value of } \\
\text { excavation stage/mm }\end{array}$ & 14 & 17 & 16 & 13 & 16 & 16 & 14 & 15 & 11 \\
\hline $\begin{array}{c}\text { Accumulated value during } \\
\text { backfill stage/mm }\end{array}$ & 5 & 4 & 5 & 6 & 4 & 5 & 4 & 4 & 6 \\
\hline Total displacement/mm & 19 & 21 & 21 & 19 & 20 & 21 & 18 & 19 & 17 \\
\hline $\begin{array}{c}\text { Proportion of displacement at } \\
\text { excavation stage }\end{array}$ & $73.68 \%$ & $80.95 \%$ & $76.19 \%$ & $68.42 \%$ & $80 \%$ & $76.19 \%$ & $77.77 \%$ & $78.95 \%$ & $64.71 \%$ \\
\hline $\begin{array}{c}\text { Proportion of displacement in } \\
\text { backfill stage }\end{array}$ & $26.32 \%$ & $19.05 \%$ & $23.81 \%$ & $31.58 \%$ & $20 \%$ & $23.81 \%$ & $22.23 \%$ & $21.05 \%$ & $35.29 \%$ \\
\hline dot & $\mathbf{s 1 1}$ & $\mathbf{s 1 2}$ & $\mathbf{s 1 3}$ & $\mathbf{s 1 4}$ & $\mathbf{s 1 5}$ & $\mathbf{s 1 6}$ & $\mathbf{s 1 7}$ & $\mathbf{s 1 8}$ & $\mathbf{A V G .}$ \\
\hline $\begin{array}{c}\text { Accumulative value of } \\
\text { excavation stage/mm }\end{array}$ & 10 & 12 & 14 & 14 & 10 & 13 & 12 & 12 & 13.33 \\
\hline $\begin{array}{c}\text { Accumulated value during } \\
\text { backfill stage/mm }\end{array}$ & 4 & 6 & 6 & 4 & 6 & 4 & 6 & 5 & 4.94 \\
\hline Total displacement/mm & 14 & 18 & 20 & 18 & 16 & 17 & 18 & 17 & 18.27 \\
\hline $\begin{array}{c}\text { Proportion of displacement at } \\
\text { excavation stage }\end{array}$ & $71.43 \%$ & $66.67 \%$ & $70 \%$ & $77.78 \%$ & $62.5 \%$ & $76.47 \%$ & $66.67 \%$ & $70.59 \%$ & $72.65 \%$ \\
\hline $\begin{array}{c}\text { Proportion of displacement in } \\
\text { backfill stage }\end{array}$ & $28.57 \%$ & $33.33 \%$ & $30 \%$ & $22.22 \%$ & $37.5 \%$ & $23.53 \%$ & $33.34 \%$ & $29.41 \%$ & $27.35 \%$ \\
\hline
\end{tabular}


Table 4 shows the proportion of the horizontal displacement at different stages. It can be seen from table 4 , the horizontal displacement deformation at excavation stage is large, about the total amount of deformation 68\% 78\%. The horizontal displacement deformation at backfill stage is large was significantly smaller, about the total amount of deformation $22 \% \sim 32 \%$.

TABLE 5

THE VERTICAL DISPLACEMENT OF THE EXCAVATION STAGE AND FILLING STAGE OF PROPORTION

\begin{tabular}{|c|c|c|c|c|c|c|c|c|c|}
\hline dot & s1 & s2 & s3 & s4 & s5 & s6 & s7 & s8 & s9 \\
\hline $\begin{array}{l}\text { Accumulative value of } \\
\text { excavation stage } / \mathrm{mm}\end{array}$ & 2.74 & 2.85 & 2.49 & 2.58 & 2.54 & 2.75 & 2.73 & 2.66 & 3.10 \\
\hline $\begin{array}{l}\text { Accumulated value during } \\
\text { backfill stage/mm }\end{array}$ & 1.39 & 2.34 & 1.64 & 1.29 & 1.22 & 1.15 & 1.52 & 1.48 & 1.79 \\
\hline Total displacement/mm & 4.13 & 5.19 & 4.13 & 3.87 & 3.76 & 3.90 & 4.25 & 4.14 & 4.89 \\
\hline $\begin{array}{l}\text { Proportion of displacement at } \\
\text { excavation stage }\end{array}$ & $66.34 \%$ & $54.91 \%$ & $60.29 \%$ & $66.67 \%$ & $67.55 \%$ & $70.51 \%$ & $64.24 \%$ & $64.25 \%$ & $63.39 \%$ \\
\hline $\begin{array}{l}\text { Proportion of displacement in } \\
\text { backfill stage }\end{array}$ & $33.66 \%$ & $45.09 \%$ & $39.71 \%$ & $33.33 \%$ & $32.45 \%$ & $29.49 \%$ & $35.76 \%$ & $35.75 \%$ & $36.61 \%$ \\
\hline dot & s11 & s12 & s13 & s14 & s15 & s16 & s17 & s18 & AVG \\
\hline $\begin{array}{l}\text { Accumulative value of } \\
\text { excavation stage/mm }\end{array}$ & 2.70 & 2.40 & 2.52 & 3.19 & 2.76 & 2.49 & 2.65 & 2.51 & 2.68 \\
\hline $\begin{array}{l}\text { Accumulated value during } \\
\text { backfill stage/mm }\end{array}$ & 1.54 & 1.43 & 1.39 & 1.96 & 1.48 & 1.47 & 1.31 & 1.38 & 1.52 \\
\hline Total displacement/mm & 4.24 & 3.83 & 3.91 & 5.15 & 4.24 & 3.96 & 3.96 & 3.89 & 4.20 \\
\hline $\begin{array}{l}\text { Proportion of displacement at } \\
\text { excavation stage }\end{array}$ & $63.68 \%$ & $62.67 \%$ & $64.45 \%$ & $61.94 \%$ & $65.09 \%$ & $62.87 \%$ & $66.91 \%$ & $64.52 \%$ & $63.84 \%$ \\
\hline $\begin{array}{l}\text { Proportion of displacement in } \\
\text { backfill stage }\end{array}$ & $36.32 \%$ & $37.33 \%$ & $35.55 \%$ & $38.06 \%$ & $34.91 \%$ & $37.13 \%$ & $33.09 \%$ & $35.48 \%$ & $36.16 \%$ \\
\hline
\end{tabular}

Table 5 shows the proportion of the vertical displacement at different stages. It can be seen from table 5 , the vertical displacement deformation at excavation stage is large, about the total amount of deformation $61 \% \sim 67 \%$. The vertical displacement deformation at backfill stage is significantly smaller, about the total amount of deformation 33\% 39\%.

\section{CONCLUSION}

1 In the foundation pit project, the horizontal displacement and settlement of slope changes over time gradually increasing.

2 In the excavation stage, different supporting forms have great influence on the horizontal displacement of foundation pit slope. The effect of different supporting forms on the vertical displacement of the excavation stage is small.

3 The horizontal displacement of the excavation stage accounted for about $68 \% \sim 78 \%$ of total displacement, the vertical displacement of slope deformation accounted for about $61 \% \sim 67 \%$.

4 Two different kinds of support form have very little effect on the vertical displacement and horizontal displacement of foundation pit slope.

5 In the backfill stage, horizontal displacement is smaller, accounting for about $22 \% \sim 32 \%$ of total displacement. The vertical displacement of slope deformation is smaller, about the total amount of deformation 33\% 39\%.

\section{REFERENCES}

[1] Woo S M, Moh Z C. Geotechnical characteristics of soils in Taipei basin. In: Proceedings of the $10^{\text {th }}$ South Asian Geotechnical Conference, Special TaiwanSession, Taipei, 1990(2): 51-65

[2] Ou C Y, Hsieh P G Chiou D C. Characteristics of ground surface settlement during excavation. Canadian Geotechnical Journal, 1993, 30: 758-767 
[3] Wong I H, Poh T Y, Chuah H L. Performance of excavations for depressed express way in Singapore. Journal of Geotechnical and Geoenvironmental Engineering, ASCE, 1997, 123(7): 617-625

[4] Jianli Yu, Xiaonan Gong. Study on Deformation Properties of Poundation Pit Engineering[J]. China Civil Engineering Journal,2002,04:86-90.(In Chinese)

[5] Huanwei Wei, Fengbo Song, Min Yang, Jianping Sun. Simplified Calculation Method for Deformation of Composite Soil Nailing Wall[J]. Engineering Mechanics,2011,S1:156-161+166.(In Chinese). 